\title{
Bir gelişim göstergesi olarak çocukların soruları
}

\section{Children's questions as a development indicator}

\section{Makale Geçmişi \\ Geliş : 13 Mayıs 2020 \\ Düzeltme : 29 Temmuz 2020 \\ Kabul : 24 Ağustos 2020}

Makale Türü

Derleme Makale

\section{Article History}

Received : 13 May 2020

Revised : 29 July 2020

Accepted : 24 August 2020

\section{Article Type}

Review Article

\author{
Ramazan Sak ${ }^{1}$ İkbal Tuba Şahin $S_{a k}^{2}$
}

\begin{abstract}
Öz: Okul öncesi dönemde çocuklar çok fazla soru sormaktadırlar ve bu durum çoğu kez ebeveynler ve öğretmenler tarafından bir yakınma konusu olmaktadır. Oysa ki erken çocukluk yıllarında çocukların soruları, onların gelişimleri ve öğrenmeleri için oldukça önemlidir. Bu çalışmanın amacı da okul öncesi dönem çocuklarının sorularının incelenmesidir. Bu amaç doğrultusunda 1896-2020 yılları arasında çocukların sorularını konu alan çalışmalar incelenmiştir. Bu çalışmada okul öncesi dönem çocuklarının soruları onların gelişimleri açısından ele alınmış, bu soruların sınıflandırılması incelenmiş ve bu süreçte yetişkinlerin rollerine değinilmiştir. Ayrıca, çocukların soruları yaşları açısından incelenmiş ve çocukların sorularına örnekler verilmiştir. Son olarak, çocukların sorularına ilişkin ebeveyn, öğretmen ve araştırmacılara yönelik önerilere yer verilmiştir.
\end{abstract}

Anahtar Kelimeler: Okul öncesi dönem, Çocukların soruları, Çocuk gelişimi

Abstract: Children ask many questions in pre-school period so parents and preschool teachers usually complain about it. However, the questions of children in early childhood years are crucial for their development and learning. Therefore, the aim of this paper was to examine the questions of children in the preschool period from different perspectives. For this purpose, studies on children's questions between 1896-2020 were examined. In this paper, the questions of preschool children were reviewed in terms of their development, classification of children's questions was addressed and the roles of adults were mentioned in this process. Children's questions were also examined in terms of their ages, and examples of children's questions were addressed. Finally, suggestions for parents, teachers, and researchers regarding children's questions were shared.

Keywords: Preschool period, Children's questions, Child development 


\section{SUMMARY}

\section{Introduction}

Children's questions are a sign of their curiosity, interest and what they want to learn (Engel, 2011; Harlen, 1996). Questioning accepted as an information-seeking strategy appears in early childhood and develops rapidly (Ronfard, Zambrana, Hermansen, \& Kelemen, 2018). The importance of preschool years in child development and education is accepted nowadays and the attitudes and behaviors of parents and preschool teachers in these years are of vital importance. The awareness of parents and teachers about preschoolers' questions that are accepted as an indicator of their interests, curiosities, learning motivations and problemsolving skills is also very important. Children ask many questions in preschool period so parents and preschool teachers usually complain about it. However, the questions of children in early childhood years are crucial for their development and learning. Therefore, the aim of this paper is to examine the questions of children in the preschool period from different perspectives. In this paper, the questions of preschool children were reviewed in terms of their development, classification of children's questions was addressed and the roles of adults were mentioned in this process. Children's questions were also examined in terms of their ages, and their sexual questions were addressed. Finally, the studies on children's questions were mentioned and suggestions for parents, teachers, and researchers regarding children's questions were shared.

\section{Children's questions in terms of their development}

Questioning is related to mental functions and it is considered as an outcome of thinking and experiencing processes (Havigerova \& Juklova, 2011) so children's questions play an important role in their cognitive development (Chouinard, 2007). When children have a problem and their current knowledge is not sufficient for a solution, they ask some questions to find the necessary information. Thanks to asking questions, children have information structures like adults (Chouinard, 2007).

Children's questions provide adults with information about children in many ways such as syntactic, semantic/conceptual and/or pragmatic development of children (James, \& Seebach, 1982). Children's misinformation or misinterpretation based on their current knowledge can be understood through their questions (Vygotsky, 1978). When a child does not ask any questions about a particular topic, it can be assumed that the child is not ready to learn about it (Martin \& Torres, 2013). Also, children's questions and answers are seen as an evidence of their active learning, and educators support children's understanding through this process (Tizzard, Hughes, Carmichael, \& Pinkerton, 1983).

\section{Classification of children's questions and age as a variable}

Preschool children's questions are a reflection of their curiosity and motivation to learn how things work (Callanan \& Oakes, 1992). An abnormal or unexpected result is the cause of children's "why" questions (Isaacs, 1930). There are different classifications of questions such as yes-no/open questions, whquestions/disjunctive questions, 'real'/rhetorical questions, spoken/written questions and informationseeking questions (Flammer, 1981). Also, in some studies conducted by Sak (2015; 2020), the concept of 
“difficult questions" were used for some preschoolers' questions and they were defined as that adults were confused about these questions and not sure how to answer.

Children's age is accepted as a predictor related to their questioning abilities (Mills, Legare, Grant \& Landrum, 2011). For example, the youngest children mostly use what and where questions. Two-year-old children never use how, when and why questions at but use of how, when and why questions increase with age (Smith, 1933). While the number of children's questions increases once every six months up to four years old, the number of their questions decreases after age of four (Smith, 1933).

Children commonly ask their parents and teachers questions about religion, daily life, science and nature, and sexuality and fertility. Especially nowadays, children are coming across more sexually explicit materials (such as videos, pictures) compared to previous generations (Volbert, 2000). Therefore, their sexual knowledge and sexual questions increase and they use questions during their sexual socialization. Heller and Johnson (2010) examined how parents responded to common questions which children asked related to sexuality. Although some parents whose children were two to four years old talked about sexuality with their children, some parents preferred to wait up to puberty. Some parents did not discuss sexuality with their children because of some reasons such as religion, children's age and lack of knowledge (Heller \& Johnson, 2010).

\section{Children's questions and adults}

Children are ready to learn from adults to solve a mental confusion by their own questions. Adults are seen by children as reliable sources of information (Harris \& Koenig, 2006). Their qualified answers encourage children to ask different (Kurkul \& Corriveau, 2018) and more questions (Fraizer, Gelman \& Wellman, 2009). Preschool children prefer to learn from a reliable and correct source and they have the ability to choose the right person for this purpose (Was \& Warneken, 2017). They are surprisingly selective while deciding who to learn from (Corriveau \& Kurkul, 2014). When children do not get satisfying answers to their questions, they can use different ways such as rearranging their original questions or expressing them in different ways, directing their original questions to another person, stopping asking questions, or sharing their own explanations for alternative feedback (Chouinard, 2007; Frazier, Gelman \& Wellman, 2009; Sands, Carr \& Lee, 2012). Preschool children's questions are an ideal opportunity for adults to share their experiences, values and beliefs honestly (Stephens, 2007b).

\section{Conclusion and Discussion}

The questions of preschool children have an important role on their cognitive development, socialemotional development, language development, learning motivations and problem-solving skills. Therefore, adults, especially parents and preschool teachers, should be aware of the importance of these questions and tend to use them as a tool for the development and education of children. Preschoolers' questions should be answered by adults honestly, respectfully and in a simple way (Stephens, 2007b). Preschool children's experiences, ages and comprehension ability should be considered while responding to their questions (Stephens, 2007b). There is a consensus about that "Trying to find brief, simple, and age-appropriate 
answers to children's questions; understandable answers which do not overwhelm them with too many words." (Clinical Center National Institutes of Health, 2015: p. 2). To support children's cognitive, language, social and emotional development, adults' awareness and abilities should be increased about children's questions' role, importance and necessity of responding to them correctly. Therefore, several resource books, information brochures, seminars and training should be prepared. 


\section{GİRIŞ}

Soru sormak dünyayı öğrenmenin bir yolu olarak kabul edilmektedir (Ruggeri ve Lombrozo, 2015; Şahhüseyinoğlu, 2010) çünkü sorular bilgi aramada özellikle etkili bir stratejidir (Ronfard ve diğerleri, 2018). Okul öncesi dönem çocukları, yeni bir kavram öğrenmek için gerekli bilgileri edinmek amaciyla soruları etkili bir şekilde formüle edebilmektedirler (Chouinard, 2007; Kemler Nelson ve O’Neil, 2005; Mills, Legare, Bills ve Mejias, 2010). Ayrıca, okul öncesi dönemde soruların problem çözme stratejileri olarak kullanılmasını inceleyen Legare, Mills, Souza, Plummer ve Yasskin (2013), çocukların sorularını stratejik bir araç olarak kullanmanın, çocukların problem çözme sürecini araştırmak için ideal bir bağlam olabileceğini dile getirmişlerdir.

Çocukların soruları yetişkinlerin hayal ettiklerinden daha büyük, daha ciddi ve daha eğlenceli olarak düşünülmelidir (Olsson, 2013). Çünkü bu sorular, onların zaman geçirme yöntemleri veya yetişkinlerin dikkatini çekme aracı değildir. Aksine, onların meraklarının, ilgilerinin ve bilmek istediklerinin işaretleridir (Engel, 2011; Harlen, 1996). Yani çocukların soruları, merakın ve ilginin ifadesi için doğal bir kaynak olarak kabul edilmektedir (Hedges ve Cooper, 2016; Riihelä, 2003). Diğer bir ifadeyle, çocuklar içgüdüsel merakları yüzünden sorular sormaktadırlar (Compayre, 1902).

"Soru sorma, arada bir gerçekleşen bir şey değildir- soru sormak, çocuk olmanın anlamının merkezi bir parçasıdır" (Chouinard, 2007; s. 25). Bilgi arama stratejisi olarak kabul edilen soru sorma, erken çocukluk yıllarında ortaya çıkmakta ve hızlı bir şekilde gelişmektedir. Örneğin, okul öncesi dönem çocukları mevcut bilgilerine güvenmediklerinde veya yeni bir sorunla karşılaştıklarında bilgi aramak için soru sormakta (Ronfard ve diğerleri, 2018) veya bazı nesnelerin adlarını bilmek veya bir şeylerin nasıl çalıştığını öğrenmek gibi bazı problemlerini çözmek için başkalarından yardım alabilmektedirler (Was ve Warneken, 2017). Çocukların kavramsal olarak önemli kabul ettiği nesnelerin özellikleri de soruları ile ortaya çıkabilmektedir (Greif, Nelson, Keil ve Gutierrez, 2006).

Küçük çocuklar etraflarındaki dünyayla ilgili oldukça meraklıdırlar ve bu meraklarını, öğrenme sürecinde çok aktif bir şekilde doğrudan deneyimleyerek ve başkalarından bilgi alarak gidermektedirler (Was ve Warneken, 2017). Bu dönemde çocuklar, aktif olarak bilgi edinmek için motive olmakta ve bunun için belirli konuşma tekniklerini kullanmaktadırlar (Frazier, Gelman ve Wellman, 2009). Çocuklar için bilgi edinmenin önemli bir yolu olan soru sorma (Kemler-Nelson, Egan ve Holt, 2004) aynı zamanda kişiler arası iletişimde de önemli bir konuşma eylemidir (Goody, 1978). Ancak, Chouinard (2007) çocukların soruları başka amaçlardan ziyade daha çok bilgi toplamak için kullandıklarını vurgulamış; Riihelä (2003) da soruların, çocuklar için bilgi kaynaklarını keşfetmek ve kişisel deneyimleri ile başkalarından edindikleri bilgileri birleştirmek için çok önemli 
olduğunu ifade etmiştir. Bereiter (2002) çocukların en bilge sorularının nadiren o anki etkinliklerle ilgili olduğunu ve bu soruların dünyanın şekli, doğum, ölüm, iyilik, kötülük, güç, tehlike, hayatta kalma, cömertlik ve macera gibi daha büyük konularla ilgili olduklarını belirtmiștir.

Çocukların içinde bulundukları sosyal bağlam onların soru sorma eylemlerini şekillendiren bir unsurdur. Başka bir deyişle, çocuklar bir soru sormak istediklerinde soru sorulacak kişinin uygunluğunu ve ortamı dikkate almaktadırlar (Ronfard ve diğerleri, 2018). Okul öncesi dönemde çocukların içinde bulundukları en önemli iki ortam, ev ve okuldur. Okul öncesi öğretmenleri ve okul öncesi dönem çocukları arasındaki uzun diyaloglar erken çocukluk eğitiminde kalite göstergelerinden biri olarak kabul edilmektedir (Sylva, Melhuish, Sammons, Siraj-Blatchford ve Taggart, 2010). Okul öncesi dönemde çocukların soru sorma konusunda gelişmiş becerilerinde bir artış olmasının (Corriveau ve Kurkul, 2014) da bir sonucu olarak, yapılandırmacı öğretmenler çocukların ilgilerini öğrenmek, müdahalelerini şekillendirmek ve planlama yapmak için onların sorularını kullanmaktadırlar (Birbili ve Karagiorgou, 2010).

Çocukların soruları, eğitim, bilişsel psikoloji ve dilbilim gibi farklı araştırma alanlarından araştırmacılar tarafindan incelenmiş (Bova, 2011), birçok araştırmanın konusunu oluşturmuştur. Özellikle gelişim psikolojisinin uzun süredir çalışıla gelen konulardan biri olmakla birlikte (Harris, 2000; Harris ve Koenig, 2006; Isaacs, 1930; Piaget, 1926), dil açısından da çocuk soruları çokça çalışılmaktadır (Bloom, Merkin ve Wootten, 1982; Brown, 1968; Cairns ve Hsu, 1978; Tyack ve Ingram, 1977; Valian ve Casey, 2003; Wode, 1971). Çocukların sorularına ilgi duyan ilk araştırmacılardan biri olan Sully (1896), 3-6 yaş arasındaki çocukların "neden” tarzı sorularını incelemiştir. Sully'den yaklaşık yüzyıl sonra, çocukların “neden” sorularının işlevleri aile konuşmaları bağlamında incelenmiştir (Bova, 2011). Frazier ve diğerleri (2009) açıklayıcı bilgi almak için okul öncesi dönem çocuklarının yetişkinlerle görüşmelerinde sordukları soruları ele almışlardır. Bir başka çalışmada ise, okul öncesi dönem çocuklarının bilmedikleri eşyalar ve hayvanlar ile ilgili soruları, çocukların ne bilmek istedikleri bağlamında incelenmiştir (Greif ve diğerleri, 2006). Callanan ve Oakes (1992) okul öncesi dönem çocuklarının sorularının onların kavramsal yapıları üzerindeki etkilerini araştırırken bazı araştırmacılar, okul öncesi dönemde soruların problem çözme stratejileri olarak kullanılmasını incelemişlerdir (Legare ve diğerleri, 2013; Mills ve diğerleri, 2011). Ayrıca, çocukların soruları akademik başarı ile ilgili olarak da ele alınmıştır (Blank ve Covington, 1965; Ross ve Killey, 1977). Silva ve diğerleri (2014) çocukların sorularını cevaplamanın onların tutarlı hikayeler oluşturmaları üzerindeki rolünü incelerken, Rowland (2006) iki ve beş yaşındaki çocukların sorularındaki hataları analiz etmiştir. Yaden, Smolkin ve Conlon (1989) okul öncesi dönem çocuklarının, ebeveynleriyle hikâye okurken sordukları soruları erken okuryazarlık 
bağlamında incelemiştir. Davis (1932) tarafından çocukların soruları formlarına ve işlevlerine göre ele alınırken, Smith (1933) yaş, cinsiyet ve başkalarıyla olma durumu gibi bazı değişkenlerin okul öncesi dönem çocuklarının sorularının sıklığı, biçimi ve fonksiyonlarına etkisini incelemiştir. Özetle, okul öncesi dönem çocuklarının soruları uzun süredir özellikle gelişim bağlamında araştırılan bir konu olmasına rağmen, bu konu Türkçe alan yazında neredeyse hiç yer almamıştır.

Okul öncesi dönemin çocuk gelişimi ve eğitimindeki önemi günümüzde kabul görmüş bir durum olup (Essa, 2013; Morrison, 2018, 2019; Nightingale ve Payne, 2013; Sak, Şahin-Sak, Öneren-Şendil ve Taşkın, 2020), bu yıllarda ebeveynlerin ve okul öncesi öğretmenlerinin tutum ve davranışları oldukça önemlidir. Çocukların ilgilerinin, meraklarının, öğrenme motivasyonlarının ve problem çözme becerilerinin bir göstergesi olarak kabul edilen sorular konusunda da ebeveyn ve öğretmenlerin farkındalıkları kritik bir öneme sahiptir. Bu çalışmada, okul öncesi dönem çocuklarının soruları onların gelişimleri açısından incelenmiş, bu soruların sınıflandırılması ele alınmış ve sorular karşısında yetişkinlerin rollerine değinilmiştir. Ayrıca, çocukların soruları yaşları açısından değerlendirilmiş ve çocukların sorularına örnekler verilmiştir. Son olarak, çocukların sorularına ilişkin ebeveyn, öğretmen ve araştırmacılara yönelik önerilere yer verilmiştir.

\section{Çocukların gelişimi açısından çocukların soruları}

Çocukların gelişimi, çocukların bilinmeyenleri anlama çabaları ile desteklenmektedir (Piaget, 1969). Çocukların soruları da bu süreçte bilişsel becerilerinin tetikleyicisi olarak kabul edilmekte ve çocukların gelişim düzeyleri ile ilgili önemli bir kriter olarak düşünülmektedir (Havigerova ve Juklova, 2011; Piaget, 1926). Soru sormak zihinsel işlevlerle ilişkili olup, düşünme ve deneyimleme süreçlerinin bir ürünü olarak kabul edilmektedir (Havigerova ve Juklova, 2011). Soru sormak çok sıradan bir aktivite gibi görünse de aslında bir dizi bilişsel sürecin bir ürünüdür. Ronfard ve diğerleri (2018) soru sorma sürecini aç1klamak için dört bileşenden oluşan bir soru sorma modeli önermişlerdir. Bu bileşenler (Ronfard ve diğerleri, 2018; s. 3):

(1) Başlatma (initiation): "Bilginin eksik ve gerekli olduğunun farkına varılmasıyla harekete geçmek."

(2) Formülleştirme (formulation):

“a) Hangi bilgilerin sorulacağını belirlemek (ve hangi olası cevaplar olabilir),

b) Sorunun anlaşılması için soruyu ifade etmek." 
(3) İfade (expression): Sorunun birine sormaya değer olup olmadığına karar vermek.

a) Birinin güvenilir bilgi sağlamak için uygun olup olmadığını belirlemek.

b) Eğer böyle bir kişi uygunsa, bu kişiden bu bağlamda bilgi talep etmenin kabul edilebilir olup olmadığına karar vermek."

(4) Cevap değerlendirme ve takip etme (response evaluation and follow-up): Cevabı değerlendirmek ve ek bilgiye ihtiyaç olup olmadığına karar vermek."

Çocukların bilişsel gelişiminde sorular önemli bir role sahiptir. Çocukların bir sorunu olduğunda ve mevcut bilgileri çözüm için yeterli olmadığında, soru sorarak yetişkinler gibi bilgi yapılarına sahip olmaktadırlar (Chouinard, 2007). Anormal veya beklenmedik bir durumla karşılaştıklarında, çocuklar "neden" sorusunu sorarak mevcut duruma bir açıllama almaya çalışmaktadırlar (Isaacs, 1930). Bilgi toplama amaçlı soru sorma ve bu soruların cevaplarını kullanma süreci çocukların kavramsal yapılarını ve problem çözme becerilerini etkilemektedir. Ayrıca soruların temel işlevi, çocukların dünyayı keşfetmelerini desteklemek ve çocukların bilişsel gelişimine yardımcı olmaktır (Chouinard, 2007).

Çocukların sorularını inceleyen ilk araştırmacılardan biri olarak Piaget, bu soruların önemine vurgu yapmış ve şunu belirtmiştir: "Çocuk mantığını kavramak için, kendiliğinden gelişen soruların incelemesinden daha iyi bir yol yoktur” (Piaget, 1974; s. 171). Piaget, çocukların edindikleri çeşitli ifadeleri süzgeçten geçirip organize ettiğini vurgulasa da asimilasyon sürecinin ilk elden gözlem yoluyla gerçekleşmediğini yani başkalarının ifadelerine dayandığını belirtmiştir (Harris ve Koenig, 2006). Piaget (1926) altı-yedi yaşlarındaki bir oğlan çocuğunun günlüğünü raporlamış, ancak çocuğun birçok sorusunu dile getirirken bu sorulara verilen cevapları rapor etmemiştir. Çünkü Piaget'in oradaki amacı, çocukların dünyadaki olaylar hakkında nasıl düşündüklerini anlamaktır (Piaget, 1926).

Sosyo-kültürel bağlamda Vygotsky (1978), sosyal çevrenin ve kişilerarası ilişkilerin üst düzey bilişsel beceriler üzerindeki etkisini vurgulamış, çocukların belirli bir kültürdeki araçlar, semboller ve insanlarla etkileşime girerek öğrenebildiklerini ifade etmiştir. Akranlar ve yetişkinlerle ortak etkileşim, çocukların gelişimini desteklemekte, erken öğrenme deneyimlerini şekillendirmektedir (Vygotsky, 1978). Vygotsky (1978), yetişkinlerin veya daha yetenekli akranların, bilginin çocuklar tarafından içselleştirilmesindeki rolünü açıklamak için yapı iskelesi (scaffolding) ve yakınsal gelişim alanı (the zone of proximal development) terimlerini kullanmıştır. Örneğin, okul öncesi dönem 
çocuklarının soruları, gelecekte okul başarılarında önemli bir yetenek olan tutarlı hikâyelerin üretilmesi için yapı iskelesi aracı olarak kabul edilmektedirler (Silva, Strasser ve Cain, 2014). Ebeveynler ve öğretmenler çocukların problemleri çözmeleri için onlara yeni bilgilerle yapı iskeleleri oluşturuyor olsalar da çocuklar çoğu zaman aktif olarak başkalarından bilgi almak için soru sormaktadırlar (Mills, Legare, Grant ve Landrum, 2011). Vygotsky çocukların bilişsel değişimini Yakınsal Gelişim Alanı kavramıyla açıklamışır. Yakınsal Gelişim Alanı, çocukların bağımsız olarak çözebilecekleri problemler ile sadece daha yetenekli veya bilgili insanlar yardımıyla çözebilecekleri problemler arasındaki mesafeyi göstermektedir (Vygotsky, 1978). Bu noktada, okul öncesi öğretmenleri ve ebeveynler, çocukların sorularını yanıtlamak ve bilişsel gelişimlerini desteklemek için yetenekli ve bilgili kişiler olarak kabul edilebilirler.

Erken çocukluk yıllarında, çocuklar sıklıkla epistemik işlevlerine göre sorular sormaktadırlar. Diğer bir ifadeyle, bilgi boşluklarını dolduran ya da belirsizlikleri gideren bilgileri almak için soruları amaçlı bir şekilde kullanmaktadırlar (Baldwin ve Moses, 1996; Piaget, 1929). Chouinard (2007) yaptı̆̆1 bir çalışmada ebeveynlerden topladığ1 4359 sorudan 3533'ünün çocukların bilgi alma amacıyla sorduğunu belirlemiştir. Bu noktada, küçük çocukların nedensel soruları ve çeşitli alanlarla ilgili uygun sorular soran karmaşı becerilerinin yetişkinlerden bilgi edinmek için etkili bir araç olduğu göz ardı edilmemelidir (Frazier ve diğerleri, 2009). Kemler-Nelson ve diğerleri (2004) çocukların nesneler hakkındaki belirsiz sorularını incelemişlerdir. Başka bir deyişle, çocukların "Bu nedir?” diye sorduklarında, nesnenin adını mı yoksa işlevini mi bilmek istediklerini araştırmışlar ve çalışmanın sonunda, çocuklar yeni bir nesne hakkında "Bu nedir?” diye sorduklarında, nesnenin isminden çok işlevini bilmek istediklerini ortaya koymuşlardır.

Soru sormanın küçük çocuklar üzerinde yaratıcı ve sosyodramatik yetkinlikleri canlandırmak ve zenginleştirmek, iletişim ve dil becerilerini iyileştirmek ve empati becerilerini geliştirmek gibi bazı olumlu etkileri bulunmaktadır (MacNaughton ve Williams, 1998). Çocukların soruları bizlere, onların sözdizimsel, anlamsal/kavramsal ve pragmatik gelişimleri gibi çeşitli alanlarda bilgiler sağlamaktadır (James ve Seebach, 1982). Çocukların mevcut bilgilerine dayalı yanlış bilgileri veya yanlış yorumlamaları da sordukları sorular yoluyla ortaya çıkmaktadır (Vygotsky, 1978). Bununla birlikte, bir çocuk belirli bir konuyla ilgili herhangi bir soru sormuyorsa, çocuğun konuyu öğrenmeye hazır olmadığı varsayılabilir (Martin ve Torres, 2013). Ayrıca, çocukların soruları ve cevapları, çocukların aktif öğrenmelerine kanıt olarak görülmekte ve eğitimcilerin çocukların kavrama becerilerini desteklemelerine yardımcı olmaktadır (Tizard, Hughes, Carmichael ve Pinkerton, 1983). 


\section{Çocukların sorularının sınıflandırılması ve soru örnekleri}

Okul öncesi dönem çocuklarının soruları, onların meraklarının ve motivasyonlarının bir yansımasıdır ve bir şeylerin niçin olduğunu ve çocuklar için işlerin nasıl yürüdüğ̈nü öğrenmek açısından önemlidir (Callanan ve Oakes, 1992). Bu sorular, evet/hayır soruları, açık uçlu sorular, ne, niçin, neden sorular1-ayrıştırıcı sorular, 'gerçek' sorular-sözbilime ait sorular, sözlü sorular-yazılı sorular ve bilgi arama soruları şeklinde sınıflandırılmaktadır (Flammer, 1981). Bununla birlikte Sak (2015; 2020) ve Sak ve Şahin-Sak (2020) çalışmalarında, okul öncesi dönem çocuklarının sordukları bazı sorular karşısında yetişkinlerin şaşırdıkları ve nasıl cevap verecekleri konusunda emin olamadıklarından hareketle "zor sorular" kavramını kullanmıs ve bu soruların, din, cinsellik, bilim ve günlük yaşama ilişkin olduklarını belirlemişlerdir. Samuelsson, Johanson, Davidsson ve Fors'un (2000) çalışmasında ise, okul öncesi çocuklarının sık sık ölüm, din, yeryüzü ve doğa bilimleri hakkında sorular sordukları ortaya çıkmıştır. Bununla birlikte, çocukların kültürel ve sosyal düzenler, doğal olaylar, biyoloji, nesneler ve fiziksel mekanizmalar gibi çeşitli konularda sorular sordukları da belirlenmiştir (Ronfard ve diğerleri, 2018). Fritzley ve Lee (2003), katılımcılarını 2-6 yaş arası çocukların oluşturduğu ve yöntem olarak soru sormanın kullanıldığı 377 çalışmayı incelemişlerdir. Bu çalışmalardaki araştırmacıların, çocuğun soru sorma becerisini geliştirecek "nasıl” (\%13) ve "hangi” (\%3) sorular1 yerine sıklıkla "evet-hayır" (\%43,3) soru türünde sorular sordukları belirlenmiştir. Alanyazında farklı araştırmacıların kullanmış oldukları farklı sınıflamalar olmakla birlikte okul öncesi dönem çocuklarının genelde bilgi arama soruları sordukları söylenebilir. Çocukların ebeveyn ve öğretmenlerine yönelttikleri din, günlük yaşam, fen-doğa ve cinsellik-üreme ile ilgili yaygın soru türlerine aşağıda bazı örnekler sunulmuştur:

Okul öncesi dönem çocuklarının din ile ilgili soruları. Çocukların yakın çevrelerindeki insanlardan din ve ölüm başta olmak üzere bir takım metafizik konulara ilişkin duyduklarından hareketle zihinlerinde oluşan belirsizlikleri gidermek için sordukları sorulardır. Bu sorulara örnek olarak şunlar sıralanabilir: Allah nerede? Allah bizi görür mü? Allah bizi nasıl görür? Allah dedemi sevmiyor muydu ki dedem öldü? Allah iyi mi kötü mü? Allah kim? Allah nerede? Allah yaramazlık yapan çocukları cehenneme atar değil mi? Allah'1 kim yarattı? Allah'1 neden göremiyoruz? Annemi ve öğretmenimi üzüp ağlatırsam Allah beni yakar mı? Azrail aynı anda ölecek iki kişinin canını nasıl alyyor? Ben her gün Allah'a dua ediyorum ama Allah neden bana cevap vermiyor? Onun babas1 öldü; ölenler melek mi oluyor? Öldüğümüz zaman tekrar dünyaya gelecek miyiz? Ölmeden cennete gidebilir miyiz? Ölüm nedir? Ölünce nereye gidilir? Yemeğimi bitirmezsem Allah beni taş eder mi? Allah ne kadar büyüktür? Allah savaşta çocuklar ölmeden neden onları kurtarmıyor? Biriyle küsersek cehennemde yanar mıyı? Bizi Allah mı yarattı yoksa annemiz mi doğurdu? Yemekte 
Bismillah demesek ne olur; şeytan sofraya kusar mı? (Callanan ve Oakes, 1992; Harris, 2000; Sak, 2015, 2020; Sak ve Şahin-Sak, 2020).

Okul öncesi dönem çocuklarının günlük yaşam ile ilgili soruları. Günlük yaşam akışında yetişkinlerin, çoğu zaman dikkat etmedikleri bazı konular çocukların ilgisini çekebilmektedir. Çocukların günlük yaşama ilişkin sorularına örnek olarak şunlar sıralanabilir: Neden sürekli yemek yiyoruz? Niye bazı arkadaşlarım hep aynı kıyafeti giyiyor? Silah kötü bir şey midir? Sizin yaşınızdakiler ve benim yaşımdakiler evlenebilir mi? Sonsuzluk ne kadardır? Ambulansın ışı̆̆ı neden kırmızı değil de mavidir? Annem, babamın annesine de anne diyor ama o onun annesi değil neden öyle diyor? Ben neden ablam gibi güzel değilim? Ben niye halk oyunları için seçilen iki kişiden biri değilim? Biz uzay araçlarıyla neden başka şehirlere gidemiyoruz? Neden markete para veriyoruz? Polisler bizi öldürür mü? Çöp arabası o kadar büyük çöp kovasını nasıl taşıyor? Yeşim teyze niçin benim annem olmamış? Neden herkeste telefon var? Neden hemşire oldun? Babalar neden işe gider? Neden gelinler beyaz gelinlik giyer? Televizyona giren adamlar nasıl çıkar? (Callanan ve Oakes, 1992; Harris, 2000; Sak, 2015, 2020; Sak ve Şahin-Sak, 2020).

Okul öncesi dönem çocuklarının fen-doğa ile ilgili soruları. Okul öncesi dönem çocukları çoğu zaman bir bilim insanı gibi fen ve doğayla ilgili konuları anlamaya çalışmaktadırlar. Çocukların fen ve doğayla ilgili sorularına örnek olarak şunlar verilebilir: Balıklar suda nasıl nefes alır? Balıklar uyur mu? Boyumuz nasıl uzuyor? Çiçekler nasıl kendi kendine büyür? Evren neden karanlı? Gökyüzü neden mavidir? Güneş dünyadan ne kadar uzaklıktadır? İç organlarımızı görebilir miyiz? İnsanlar görünmez olabilir mi? Neden biz de kollarımızı çırptığımızda uçamıyoruz? Sinekler kışın nereye gider? Tirtılın kaç bacağı var? Uçaklar nasıl uçar? Uzay nasıl oluşmuş? Yağmur nasıl oluşur? Yağmur yağdığında güneş neden 1slanmıyor? Benim tenim neden siyah? Böcekler su üstünde nasıl yürüyebiliyor? Ezginin gözleri mavi, benim ki niye siyah? Gemiler neden suda batmaz? Güneş niye akşamları sönüyor? Hayvanlar neden kış uykusuna yatar? Hayvanlar neden konuşamazlar? İnsanlar neden tuvaletini yapar? Neden göbek deliği var? Neden kar yağar? Neden soğuk havalarda ağzımızdan buhar çıkar? Saçımız kesildiğinde neden canımız acımaz? Uçaklar neden düşmüyor? Kırmızı renk neden boğayı kızdırır? (Callanan ve Oakes, 1992; Harris, 2000; Sak, 2015, 2020; Sak ve Şahin-Sak, 2020).

Okul öncesi dönem çocuklarının cinsellik-üreme ile ilgili soruları. Günümüzde okul öncesi dönem çocukları önceki nesillere kıyasla daha fazla cinsel içerikli materyallere (videolar, fotoğraflar) maruz kalmaktadırlar (Volbert, 2000). Bu yüzden de cinsel bilgi ve cinsellik içerikli soruları artmakta, kendi cinsel sosyalleşmeleri sırasında soruları kullanmaktadırlar (Martin ve Torres, 2013). 
Heller ve Johnson (2010) ebeveynlerin çocukların cinsellik ile ilgili yaygın olarak sordukları sorulara nasıl yanıt verdiklerini incelemiştir. İki-dört yaş arası çocukları olan bazı ebeveynler çocuklarıyla cinsellik hakkında konuşurken, bazıları bunun için ergenlik çağını beklemektedirler. Bazı ebeveynler dini sebepler, çocukların yaşı ve bilgi eksikliği gibi nedenlerden dolayı çocuklarıyla cinsellik hakkında konuşmamaktadırlar (Heller ve Johnson, 2010). Volbert (2000) ise iki ile altı yaş arasındaki bütün çocukların cinsel kimlik, vücudun cinsellikle ilgili bölümleri ve genital farklılıklar hakkında bilgi sahibi olduklarını, hamilelik, doğum ve üreme ile ilgili bilgilerinin sınırlı olduğunu ve çocukların yetişkinlerin cinsel davranışları hakkında bilgi sahibi olmadıklarını belirlemiştir. Her ne kadar Stephens (2007a), ebeveynler için okul öncesi dönem çocuklarının cinsellikle ilgili sorularına nasıl cevap verebilecekleriyle ilgili bazı öneriler belirtmiş olsa da, çocuklar için yaşa uygun cinsel bilginin ne olduğu konusunda fikir birliği bulunmamaktadır (Volbert, 2000).

Çocukların cinsellik ve üremeye ilişkin sorularına örnek olarak şunlar sıralanabilir: Aşk nedir? Cansu yanıma gelince neden bu kadar mutlu oluyorum ki? Çocuk nasıl olur? Anne babalarımız eğer bebek yapmayacaklarsa neden birlikte yatıorlar? Ben dünyaya nasıl geldim? Ben nasıl doğdum? Biz annemizin karnında nasıl büyürüz? Doğmadan önce neredeydim? Neden evlendiniz? Neden benim pipim yok? Sizi anneniz mi doğurdu? Karnındayken ben nasıl nefes alıyordum? Anne senin göğüslerin neden babamınkinden daha büyük? Ben de civciv gibi yumurtadan mı çıtım? Neden ben sünnet oluyorum? Niçin erkekler doğurmaz da hep kadınlar doğurur? Anne sen niye benim öğretmenimle evlenmiyorsun? Anne senin de pipin var mı? Anne ben baba olayım mı, baba nasıl olunur? Anne senin memenden neden süt geliyor yoksa sen inek misin? Anne ben de büyüyünce babamla mı evleneceğim? Niye beni kardeşlerimle beraber doğurmadın, ablam niye benden önce doğdu? (Callanan ve Oakes, 1992; Harris, 2000; Sak, 2015, 2020; Sak ve Şahin-Sak, 2020.

\section{Çocukların soruları ve yaş değişkeni}

Çocukların yaşları onların soru sorma yeteneklerine ilişkin bir yordayıcı olarak kabul edilmektedir (Mills ve diğerleri, 2011). Örneğin, on sekiz aylık çocuklar "kim" ve "ne" sorularılyla soru sormaya başlamaktadırlar (Havigerova ve Juklova, 2011). Çocuklar çok küçükken çoğunlukla "ne” ve "nerede" sorularını kullanmaktadırlar. İki yaşında ise, "nasıl”, "ne zaman” ve "neden” sorularını hiç kullanmazlar. Ancak, "nasıl”, "ne zaman” ve “neden” soruları yaş artışıyla birlikte artmaktadır. Çocukların sorularının sayısı dört yaşa kadar her altı ayda bir artarken, dört yaştan sonra azalmaktadir (Smith, 1933).

Mills ve diğerleri (2010) 3-5 yaşlarındaki çocukların yeni bilgiler edinmek için soru kullanma becerilerini deneysel bir çalışma ile araştırmış, soruların etkililiği ve soruların uygun kaynağa 
sorulmasının çocukların yaşlarına göre değiştiğini belirlemişlerdir. Bulgulara göre, beş yaşındaki çocukların dört ve üç yaşındaki çocuklara göre daha fazla uygun kaynağa soru sordukları ve sorularının daha etkili olduğu bulunmuştur. Ayrıca, üç yaşındaki çocukların sorularının genellikle doğru bilgiyi bulmak için etkili olmadığı, dört yaşındaki çocukların sorularına cevap verecek doğru kişiyi bulma konusunda üç yaşındaki çocuklardan daha iyi olduğu, bununla birlikte, dört yaşındaki çocukların hala etkili sorular soracak kadar iyi olmadıkları belirlenmiştir. Beş yaşındaki çocuklar ise, genelde onlara bilgi verecek doğru kişilere etkili sorular sormak konusunda iyidirler (Mills ve Landrum, 2016; Mills ve diğerleri, 2011).

James ve Seebach (1982), okul öncesi dönem çocuklarının sorularının pragmatik işlevini incelemiş ve yaşın, okul öncesi dönem çocuklarının sorularının işlevi ile ilgili bir yordayıcı olduğunu belirlemişlerdir. İki ve üç yaşındaki çocukların sorularının ana işlevinin bilgi arama olduğu ancak, dört ve beş yaş grubu çocuklarda soruların bilgi arama, konuşma ve yol gösterme olmak üzere üç fonksiyona daha eşit bir şekilde dağıldığı bulunmuştur (James ve Seebach, 1982).

Çocukların soru sorma performansları aynı yaşta benzer olmasına rağmen, sosyo-ekonomik düzeyleri, ebeveynlerinin ebeveynlik tutumları, ebeveynlerinin stres düzeyi, ev ve okuldaki konuşma ortamı gibi bireysel farklılıkları bu performansı etkileyebilmektedir (Ronfard ve diğerleri, 2018). Ayrıca yaş değişkeni, çocukların sordukları sorulara aldıkları doğrudan açıklamalara ilişkin tercihleri için de bir belirleyici olarak kabul edilmektedir. Örneğin, beş yaşındaki çocuklar doğrudan açıklamalar yerine doğrudan olmayan açıklamaları tercih etseler de üç yaşındaki çocuklar sadece açıklamalar kısaltıldığında doğrudan olmayan açılamaları tercih etmektedirler (Corriveau ve Kurkul, 2014).

\section{Çocukların soruları ve yetişkinler}

Çocuklar dünyayla ilgili bilgileri ilk elden keşif yoluyla edinmekte veya diğer insanlardan öğrenmektedirler (Ronfard ve diğerleri, 2018). Okul öncesi dönem çocuklarının kendi problemlerini çözmek için önceki bilgileri yetersiz kaldığında dışarıdaki kaynaklardan yardım almaları gerekmektedir. Bu durumda da sıklıkla diğer insanlardan bilgi edinmek için sorular sormaktadırlar (Mills ve diğerleri, 2010). Bir başka ifadeyle, çocuklar kendilerinin keşfedemeyecekleri fikirler ve varlıklar hakkındaki bilgileri, sorular sayesinde başka insanlardan öğrenebilmektedirler (Harris ve Koenig, 2006; Ronfard ve diğerleri, 2018).

Çocuklar yaşadıkları zihinsel bir karmaşayı kendi soruları ile çözmek için bir yetişkinden bilgi almaya hazırdırlar (Harris ve Koenig, 2006). Özellikle de din gibi gözlemlenemeyen olguları 
anlamlandırmaya çalışırken yetişkinlerin açıklamaları önemli olmaktadır (Canfield ve Ganea, 2014). Bununla birlikte, okul öncesi dönem çocukları mevcut bilgilerinden emin olmadıklarında veya yeni bir sorunla karşılaştıklarında bilgi aramak için yetişkinlere sorular sorarken (Ronfard ve diğerleri, 2018), sözlü sorular kadar sözel olmayan jestlerini de kullanarak aktif bir şekilde bilgi edinmeye çalışmaktadırlar (Harris, Bartz ve Rowe, 2017). Yani bu dönem çocukları yetişkinlerle konuşmaları sırasında aktif olarak açıklayıcı bilgiler aramaktadırlar (Frazier, Gelman ve Wellman, 2016).

Yetişkinler, okul öncesi dönem çocukları tarafından bir şeyin nasıl adlandırıldığı hakkında bilgi sağlayacak etkili kaynaklar olarak kabul edilmekte, çocuklar tarafindan güvenilir bilgi kaynakları olarak görülmektedirler (Engel, 2011; Harris ve Koenig, 2006). Onların nitelikli cevapları çocukları farklı sorular sormaya teşvik etmekte (Kurkul ve Corriveau, 2018), bu açıklamalar sayesinde çocuklar daha fazla soru sorma firsatına sahip olabilmektedirler (Frazier ve diğerleri, 2009). Çocuklar, dünya hakkında daha fazla bilgi edinmek için, daha bilgili akranlarına ve yetişkinlere sorular sormakta (Harris, 2012a), ancak bunu yaparken sorularına cevap verenlerin bilgilerini ve ortamın konuşma normlarını göz önünde bulundurmaktadırlar (Ronfard ve diğerleri, 2018). Çünkü okul öncesi dönem çocukları, sorularını sormak için uygun kişiyi tanımlama yeteneğine sahiptirler (Mills, ve diğerleri, 2010). Örneğin VanderBorght ve Jaswal (2009), okul öncesi dönem çocuklarının yiyeceklerin besin değerine ilişkin sorularını yetişkinlere sorduklarını, oyuncaklarla ilgili sorularını ise çocuklara sormayı tercih ettiklerini belirlemişlerdir. Başka bir deyişle, okul öncesi dönem çocukları için bazı konularla ilgili olarak akranları iyi bir bilgi kaynağı olarak kabul görseler de (VanderBorght ve Jaswal, 2009), okul öncesi öğretmenleri özellikle zor sorular konusunda onlar için en iyi bilgi kaynağı olarak kabul edilmektedirler.

Okul öncesi dönem çocukları, güvenilir ve doğru bir kaynaktan öğrenmeyi, bilgi edinmeyi tercih etmekte ve bunun için de doğru kişiyi seçmektedirler (Was ve Warneken, 2017) ve kimden öğreneceklerine karar verirken şaşırtıcı bir şekilde seçicidirler (Corriveau ve Kurkul, 2014). Örneğin, yeni bir kelime öğrenmeye çalıştıklarında önceki deneyimlerine dayanarak nesneleri daha önce doğru şekilde isimlendiren doğru kişiyi seçmektedirler (Koenig, Clement ve Harris, 2004). Bu nedenle, çocuklarla vakit geçiren yetişkinlerin çocukların sorularını doğru şekilde cevaplandırmaları, onları doğru şekilde bilgilendirmeleri oldukça önemlidir.

Corriveau ve Kurkul'un çalışması (2014), okul öncesi dönem çocuklarının, sordukları sorulara yetişkinler tarafindan yapılmış olan açıklamaların kalitesini değerlendirme yeteneğine sahip olduklarını göstermiştir. Ayrıca, bu dönemde çocuklar sadece açıklamaların kalitesine odaklanmamakta, aynı zamanda cevaplayıcının gelecekteki güvenilirliği ile ilgili yargılarda da 
bulunmaktadırlar. Çocuklar bilgi verenlerin gelecekteki güvenilirliğine karar verirken sordukları "ne" ve "nerede" tarzı sorularına cevaplayıcının verdiği hem tek kelimelik cevaplarına hem de "niçin" ve "nasıl” tarzı sorularına aldıkları açıklamalarına odaklanmaktadırlar (Corriveau ve Kurkul, 2014).

Çocukların sorularına cevap veren kişilerin davranışları, çocukların cevap veren kişiye güven duymaları veya onlardan şüphe duymaları üzerinde etkili olmaktadır. Örneğin cevap veren kissinin kaşığa benzeyen bir nesne için "ben bunun bir kaşık olduğunu düşünüyorum" demesi durumunda çocuk ona daha az güvenecektir. Ancak "Bu bir kaş1k" şeklinde daha net cevap verirse çocuğun cevaplayıcıya güveni artacaktır. Ayrıca, 3 yaşındaki çocuklar cevaplayıcının daha önce bariz bir isimlendirme hatası yapmış olması veya belirsizlikle konuşması durumunda ona daha şüpheyle yaklaşmaktadırlar (Jaswal ve Malone, 2007). Oldukça iyi gözlemciler olarak çocuklar, yetişkinlerin bedenlerinden, yüzlerinden, ellerinden ve yürümelerinden gelen mesajları okumaktadırlar. Yetişkinler yaptıklarıyla, söyledikleriyle ve söylemedikleriyle kendilerini açı̆̆a vurmaktadırlar (Clinical Center National Institutes of Health, 2015). Bilgi veren kimseler kendi söylediklerine inandıklarında, çocukların da onlara inanma olasılığı artmaktadır (Jaswal ve Malone, 2007).

Çocukların sorularına cevap alma durumlarına veya verilen cevabın niteliğine bağlı olarak çocuklar farklı stratejiler geliştirmektedirler. Örneğin, ebeveynler sorularına cevap vermediklerinde, çocuklar cevap için sorular sormaya devam etmekte (Chouinard, 2007), verilen cevaptan memnun olmadıklarında yine daha fazla soru sormaktadırlar (Ronfard ve diğerleri, 2018). Bir başka ifadeyle, okul öncesi dönem çocukları, sorularına tatmin edici (bilgilendirici) bir cevap alamadıklarında bir takip sorusu sormaya devam etmektedirler (Kurkul ve Corriveau, 2018; Ronfard ve diğerleri, 2018). Buna ilave olarak, asıl sorularını yeniden düzenlemek veya farklı şekillerde ifade etmek, orijinal sorularını başka bir kişiye yönlendirmek, soru sormayı bırakmak veya alternatif geri bildirimler almak için kendi açıklamalarını paylaşmak gibi farklı yollar kullanabilmektedirler (Chouinard, 2007; Frazier ve diğerleri, 2009; Sands, Carr ve Lee, 2012).

Çocuklar genellikle yetişkinlerin sorulara verdikleri ilk açıklamalardan memnun kalmamakta, bu nedenle de zorlamaları sonucu bir açıklama alana kadar veya hayal kırıklığı içinde pes edene kadar daha fazla açıklama yapılmasını istemektedirler (Baum, Danovitch ve Keil, 2008). Yani çocuklar soru sormayı bilgi almak amacıyla kullandıklarında, tatmin edici bir cevap almak için de 1srar etmektedirler (Chouinard, 2007; Kurkul ve Corriveau, 2018; Frazier ve diğerleri, 2009). Ayrıca, bilgisiz, yetersiz bir cevap aldıklarında sorularının takipçisi olurken, cevap yeterince bilgilendirici 
ise, cevap verene karşı aşırı derecede eleştirici tutumlar sergilememektedirler (Ronfard ve diğerleri, 2018).

Callanan ve Oakes (1992) 30 okul öncesi dönem çocuğunun sorularını ve ebeveynlerinin günlük etkinlikler sırasındaki açıklamalarını incelemişler, çocukların sorularının, sosyal ve fiziksel nedensellik konusundaki meraklarını yansıttı̆̆ını belirlemişlerdir. Araştırmacılar ayrıca, ebeveynlerin okul öncesi dönem çocuklarının "neden” ve "nasıl” sorularını cevaplarken, çoğunlukla nedensel açıklamalar yaptıklarını ortaya koymuşlardır (Callanan ve Oakes, 1992). Frazier ve diğerleri (2009) ise, çocukların sorularını ve ebeveynlerinden aldıkları cevaplara nasıl tepki verdiklerini incelemiş, çocukların neden ve nasıl sorularıyla ilgili açıklama aldıklarında tatmin olduklarını ve aynı konuyla ilgili yeni bilgiler almak için motive olduklarını, sorularına bir açıklama alamadıklarında ise ya kendi sorularını 1srarla tekrar sorduklarını ya da kendi açıklamalarını sunduklarını belirlemişlerdir.

Çocukların soru sordukları yetişkinlerin başında ebeveynleri ve öğretmenleri gelmektedir. Tizard ve Hughes (1984) okul öncesi dönem çocuklarının ebeveynlerine öğretmenlerinden daha fazla soru sorduklarını belirlemişlerdir. Chouinard (2007) ise çocukların evde anneleriyle birlikte olduklarında saatte ortalama 76 bilgi sorusu sorduklarını ifade etmiştir. Çocuklar ebeveynlerini bir bilgi kaynağı olarak gördükleri için onlara sorular sormaktadırlar (Callanan, 2006). Okul öncesi öğretmenleri çocukların düşünme ve öğrenmeleri üzerinde önemli bir etkiye sahiptir (Salmon, 2010) çünkü ebeveynlerin evde çocuklarıyla konuştukları kadar okul öncesi öğretmenleri de sınıflarında çocuklarla konuşmaktadırlar (Test, 1988). Okul öncesi dönem çocuklarının soruları yetişkinlerin deneyimlerini, değerlerini ve inançlarını dürüstçe paylaşmaları için ideal bir firsat olarak düşünülebilir (Stephens, 2007b).

Yetişkinlerin okul öncesi dönem çocuklarının sorularına verdikleri cevaplar çeşitli araştırmacılar tarafindan incelenmiştir (Callanan ve Jipson, 2001; Callanan ve Oakes, 1992; Chouinard, 2007; Frazier ve diğerleri, 2009; Sak, 2015; 2020; Tizard ve diğerleri, 1983). Yetişkinlerin çocukların sorularına verdikleri cevaplara ilişkin alan yazında birbiriyle zıt olabilecek araştırma bulguları bulunmaktadır. Örneğin bazı çalısmalarda, yetişkinlerin çocukların sorularına karşıllk yaptıkları açıklamaların zaman zaman nitelikli olmadığı (Kurkul ve Corriveau, 2018), yetişkinlerin bu soruları her zaman çocukları tatmin edecek şekilde cevaplamadıkları (Martin ve Torres, 2013) ve çocukların sorularına cevap verme konusunda yetişkinlerin isteksiz oldukları (Tizard ve diğerleri, 1983) belirtilmiştir. Bununla birlikte, çocukların soruları karşısında yetişkinlerin "fikrim yok" demek, "geçiştirmek", "bilgi aktarmak”, “alternatifler sunmak”, "somut açıklamalar yapmak” ve "çocuğu rahatlatmak" gibi stratejiler kullandıkları belirlenmiştir (Samuelsson ve diğerleri, 2000). Bazı 
çalışmalarda ise günlük etkinlikler sırasında yetişkinlerin çocuklara birçok konu ile ilgili zekice ipuçları verdikleri, çocukların yaşına ve gelişimine uygun bir dil kullandıklanı (Callanan, 2006) ifade edilmiştir. Kemler Nelson ve O'Neil (2005) çocukların nesnelerin kimliğine ilişkin sorularına ebeveynlerin verdikleri cevapları araştırmışlar ve ebeveynlerin cevaplarını çocukların önceki bilgilerine dayanarak düzenlediklerini belirlemişlerdir. Frazier ve diğerleri (2016), okul öncesi dönem çocuklarının, açıklayıcı sorularına karşılık yetişkinlerin yaptıkları açıklamalara ilişkin memnuniyetlerini incelemişler, çocukların yetişkinlerden gelen açıklamalardan memnun kaldıklarını ancak sorularına cevap alamadıklarında soru sormaya devam ettiklerini ortaya koymuşlardır. Kurkul ve Corriveau (2018) günlük konuşmalar sırasında okul öncesi dönem çocuklarının soru türlerini, bu sorulara yetişkinlerin vermiş oldukları cevapların kalitesini ve çocukların yetişkinlerin cevaplarına verdikleri tepkileri incelemişlerdir. Çocukların sorularına orta sosyo-ekonomik düzeydeki yetişkinlerin düşük sosyo-ekonomik düzeydeki yetişkinlerden daha fazla açıklayıcı ve doğrudan cevaplar verdikleri bulunmuştur (Kurkul ve Corriveau, 2018).

Türkiye'de yapılmış bazı çalışmalarda da okul öncesi dönem çocuklarının soruları ve yetişkinlerin bu sorulara verdikleri cevaplar incelenmiştir (Sak, 2015; 2020; Sak ve Şahin-Sak, 2020). Sak (2015) okul öncesi dönem çocuklarının zor sorularını ve ebeveynlerinin bu sorulara cevaplarını incelemiştir. Ebeveynlerin cevapları incelendiğinde ortaya çıkan yedi temadan (örneklerle gerçekçi cevaplar vermek, örnekler olmadan gerçekçi cevaplar vermek, yanlış açıklamalar yapmak, tamamen dini açıklamalar yapmak, soruyu cevapsız bırakmak, yetersiz cevap vermek ve tehdit etmek ya da caydırmak) sadece ikisinin uygun cevapları (hem gelişime uygun hem gerçekçi) içerdiği belirlenmiştir. Sak (2020) tarafından 324 okul öncesi öğretmeni ile yapılan bir diğer çalışmada, öğretmenlere sınıflarındaki çocuklar tarafindan sorulan zor sorular ve öğretmenlerin bunlara verdiği cevaplar incelenmiştir. Çalışmanın sonunda, çocukların zor sorularının fen ve doğa, din, cinsellik ve üreme, günlük yaşam olmak üzere dört grupta toplandığ1 belirlenmiştir. Okul öncesi öğretmenlerinin cevaplarının ise, gerçekçi cevaplar, yetersiz cevaplar, yanlış açıklamalar ve cevapsız bırakma ve ilgisiz cevaplar şeklinde olduğu ifade edilmiştir. Sak ve Şahin-Sak (2020) okul öncesi dönem çocuklarının ebeveynleri ve öğretmenlerine sordukları zor soruları cinsiyet değisskeni açısından incelemişlerdir. Çalışmaya 131 ebeveyn ile 131 okul öncesi öğretmeni katılmıştır. Kızların erkeklere göre cinsiyet ve doğurganlık hakkında dört kat daha fazla ve günlük yaşamla ilgili yaklaşık iki kat daha fazla zor soru sordukları belirlenmiştir. Erkeklerin ise din, bilim ve doğa ile ilgili daha çok soru sordukları bulunmuştur. Cinsellik ve doğurganlık sorulanı babalara göre daha çok annelere yöneltilirken, çocuğun cinsiyeti ne olursa olsun babalara din ve günlük yaşam soruları daha çok sorulmuştur. Bununla birlikte, çocukların öğretmenlerine bilim ve doğa ile ilgili soruları 
ebeveynlerinden daha fazla sordukları, din, cinsiyet ve doğurganlık hakkında ise daha az soru sordukları belirlenmiştir.

Çocukların sorularıyla ilişkili diğer önemli bir konu da yetişkinlerin rolüdür. Çocuklar yetişkinleri gözlemleyerek ve yetişkinlerle etkileşime geçerek sorularını biçimlendirmektedirler (Birbili ve Karagiorgou, 2010). Bu nedenle yetişkinler, çocuklara soru sormayla ilgili iyi bir rol model olmalıdırlar. Örneğin bir rol model olarak yetişkinlerin soru sorma davranışları çocukların soru türlerini ve sıklığını etkileyebilmektedir (Birbili ve Karagiorgou, 2010). Ayrıca çocuklar ve yetişkinler arasındaki duyarlı konuşmalar sayesinde çocuklar kendilerini daha yetenekli ve öz-güvenli hissetmektedirler (Test, Cunningham ve Lee, 2010).

\section{SONUÇ VE ÖNERİLER}

Okul öncesi dönem çocuklarının soruları onların bilişsel gelissimleri başta olmak üzere, sosyalduygusal gelişimleri, dil gelişimleri, öğrenme motivasyonları ve problem çözme becerileri üzerinde önemli bir role sahiptir. Bu nedenle başta ebeveynler ve okul öncesi öğretmenleri olmak üzere yetişkinlerin, çocukların sorularının önemi konusunda farkındalık sahibi olmaları ve çocukların gelişimi ve eğitimi açısından onların sorularını bir araç olarak kullanma eğilimlerinin olması gerekmektedir.

Yapılan alanyazın taramasında bazı çalışmalarda yetişkinlerin çocukların sorularına uygun cevaplar verdikleri, verilen cevapların niteliğinin çocuklarının gelişimini destekleyici özellikte olduğu vurgulanırken, bazı çalışmalarda ise yetişkinlerin çocuklara cevap verme konusunda isteksiz oldukları ve uygun olmayan birtakım stratejilerle çocukların sorularının geçiştirildiği ifade edilmiştir. Erken öğrenmeler hem sorular hem de sorulara verilen açılkamaların niteliği ile şekillenmektedir (Kurkul ve Corriveau, 2018). Çocukların soruları bilişsel gelişimleri için yararlı olacaksa, çocuklar sorularına bilgilendirici cevaplar almalıdırlar (Chouinard, 2007; s. 12). Hem sözlü hem de sözsüz cevaplar, bir yetişkinin çocukların soruları konusunda ne kadar rahat olduğunu göstermektedir (Stephens, 2007a). Okul öncesi dönem çocuklarının soruları yetişkinler tarafindan dürüst, saygılı ve basit bir şekilde cevaplanmalıdır. Çocukların deneyimleri, yaşları ve anlama yetenekleri, sorularına cevap verilirken dikkate alınmalıdır (Stephens, 2007b). Çocukların sorularına kısa, basit ve yaşa uygun cevaplar bulmaya çalışırken, çok fazla kelime ile onları boğmayan, anlaşılır cevaplar verilmesi gerektiği konusunda fikir birliği bulunmaktadır (Clinical Center National Institutes of Health, 2015; s. 2). Alanyazında, öğretmenlerin çocukların sorularına verdikleri cevaplar doğru olarak kabul edilmiş olmasına rağmen yapılan bazı açıklamaların çocukların kelime dağarcığına uygunluğu bir 
soru işareti olarak kalmaktadır. Dolayısıyla, çocukların kelime dağarcığı yetişkinlerin onların sorularına cevap verirken göz önünde bulundurmaları gereken bir diğer husustur.

Soru sormak bilişsel süreçlerin tetikleyicisidir. Özellikle erken eğitim ve bakım programları, çocukların bilişsel gelişimi üzerinde önemli olumlu etkilere sebep olmaktadır (Burger, 2010). Bu nedenle eğitim sürecinde, okul öncesi dönem çocuklarının soru sorma yeteneğini desteklemelidir (Havigerova ve Juklova, 2011). Çocuklar sorularına, bilişsel gelişimlerine faydalı olacak şekilde bilgilendirici cevaplar almalıdırlar (Chouinard, 2007). Bununla birlikte, çocukların sosyal ve duygusal gelişimi, duyarlı ve hassas bir konuşma yoluyla yetişkinler tarafindan desteklenmelidir (Test ve diğerleri, 2010).

Mercer (2000) öğretmen-çocuk iletişiminin öğrenme sürecindeki rolünü vurgulamıştır. Öğretmenler, çocukların yüksek kaliteli bilişsel gelişim becerilerini desteklemekten sorumludurlar (Tienken, Goldberg ve Dirocco, 2009). Çocuklar etkili öğrenme sınıflanında öğretmenlerine soru sorma firsatına sahip olmalıdırlar (Whittaker, 2012). İlgili alanyazında, çocukların yetişkinlere rahat soru sorabilmelerinin ve yetişkinlerin de uygun şekilde bu sorulara cevap vermelerinin önemli olduğu vurgulanmaktadır. Ancak, Sak (2020) tarafından yapılan çalışmada Türkiye'deki ebeveynlerin ve okul öncesi öğretmenlerinin okul öncesi dönemde çocuklarının zor sorularına verdikleri cevapların sadece sınırlı bir bölümünün gerçekçi olduğu belirlenmiştir. Dolayısıyla, çocukların başta bilişsel gelişimleri olmak üzere dil gelişimlerinin ve sosyal-duygusal gelişimlerinin desteklenmesi için, yetişkinlerin çocukların sorularının rolü, önemi ve doğru şekilde cevaplandırılması konularında farkındalıklarının ve becerilerinin artırılması gerekmektedir. Bunun için de birtakım kaynak kitapların, bilgi broşürlerinin, seminerlerin ve eğitimlerin verilmesi gerekmektedir.

Her ne kadar yetişkinlerin okul öncesi dönem çocuklarının boşanma (Schneider ve Zuckerberg, 1996), cinsellik (Goldman, 2010), ölüm (Goldman, 2009), evlat edinme (Herlem, 2006), din ve bilim (Baggini, 2011; Frisancho, 2011; Schleifer ve Talwar, 2009) ve diğer konular (Harris, 2012b; Hunnicutt, 1949; Jamieson, 2007) ile ilgili sorularına nasıl cevap verebileceğini içeren bazı kitaplar, makaleler bulunsa da bu kaynakların neredeyse tamamı İngilizce yazılmış kaynaklardır. Çocukların sorularına gelişimsel olarak uygun cevapları içeren Türkçe rehber kitaplara gereksinim duyulmaktadır.

Çocukların sorularına ilişkin yapılmış çalışmalar ile ilgili diğer bir ayrıntı ise, çocukların soruları şeklinde ifade edilen çalışmaların bazılarında katılımcılar yedi yaşından büyük çocuklardan oluşmuştur (Ruggeri ve Lombrozo, 2015; Ruggeri, Lombrozo, Griffiths ve Xu, 2015). Bu sebeple 
bundan sonra yapılacak çalışmalarda özellikle 2-6 yaş aralığındaki çocukların soruları incelenebilir. Okul öncesi dönem çocuklarının sorularına ilişkin yapılacak sonraki çalışmalarda, ebeveynlerin anne baba tutumları ile çocuklara verdikleri cevaplar arasındaki ilişki incelenebilir. Okul öncesi öğretmenlerinin ve ebeveynlerin okul öncesi dönem çocuklarının sorularına verdikleri sözel cevapları inceleyen çalışmalar bulunmaktadır. Ancak, iletişimde sadece sözler değil beden dili de oldukça önemlidir. Yapılacak başka çalışmalarda öğretmenlerin sözel cevaplarının yanı sıra beden dillerinin de incelendiği çalışmalar yapılabilir. Ayrıca, çocukların soruları sosyo-ekonomik durumlanına göre karşılaştırılabilir. Riihelä (2003) tarafından yapılan çalışmada olduğu gibi çocukların soruları hastane, okul, kütüphane, müze ve pazar yeri gibi farklı yerlerdeki soruların niteliği ve özellikleri açısından karşılaştırılabilir.

Çocukların sorularının nitel ve nicel özellikleri hakkındaki bilgiler sınırlıdır (Ruggeri ve Lombrozo, 2015). Bu nedenle okul öncesi dönem çocuklarının sorularının nitel ve nicel özellikleri araştırılabilir. Çocukların soruları farklı açılardan çalışılmış olsa da eğitimli kişilerin bu sorulara cevapları çalışılmamıştır (Riihelä, 2003). Yetişkinlerin eğitim durumlarına göre çocukların sorularına verdikleri cevaplar karşılaştırılabilir. Ronfard ve diğerlerinin (2018) de önerdikleri gibi, araştırmacılar çocukların sosyal etkileşimler ve belirli türden soru ve cevap değiş tokuşlarılyla genişletilmiş konuşmalar yoluyla bilgilerinin nasıl geliştiğine odaklanabilirler.

\section{KAYNAKÇA}

Baggini, J. (2011). Really really big questions about God, faith and religion. London: Kingfisher.

Baldwin, D. A., \& Moses, L. J. (1996). The ontogeny of social information gathering. Child Development, 67, 1915-1939.

Baum, L., Danovitch, J., \& Keil, F. (2008). Children's sensitivity to circular explanations. Journal of Experimental Child Psychology, 100, 146-155.

Bereiter, C. (2002). Education and mind in the knowledge age. Mahwah, NJ: Lawrence Erlbaum.

Birbili, M., \& Karagiorgou, I. (2010) Helping children and their parents ask better questions: An intervention study, Journal of Research in Childhood Education, 24(1), 18-31.

Blank, S., \& Covington, M. (1965). Inducing children to ask questions in solving problems. The Journal of Educational Research, 59(1), 21-27.

Bloom, L., Merkin, S., \& Wootten, J. (1982). Wh-questions: Linguistic factors that contribute to the sequence of acquisition. Child Development, 53, 1084-1092.

Bova, A. (2011). Functions of "why" questions asked by children in family conversations. ProcediaSocial and Behavioral Sciences, 30, 776-782. 
Brown, R. (1968). The development of wh questions in child speech. Journal of Verbal Learning and Behavior, 7, 279-290.

Burger, K. (2010). How does early childhood care and education affect cognitive development? An international review of the effects of early interventions for children from different social backgrounds. Early Childhood Research Quarterly, 25, 140-165.

Cairns, H. S., \& Hsu, J. R. (1978). Who, why, when and how: A development study. Journal of Child Language, 5, 477-488.

Callanan, M. A. (2006). Cognitive development, culture, and conversation: Harris and Koenig's "truth in testimony: how children learn about science and religion". Child Development, 77(3), 525-530.

Callanan, M. A., \& Jipson, J. I. (2001). Explanatory conversations and young children's developing scientific literacy. K. Crowley, C. D. Schunn, \& T. Okada (Ed), Designing for science: Implications from everyday, classroom, and professional settings içinde (s. 21-49). Mahwah, NJ: Erlbaum.

Callanan, M. A., \& Oakes, L. (1992). Preschoolers' questions and parents' explanations: Causal thinking in everyday activity. Cognitive Development, 7, 213-233.

Canfield, C., \& Ganea, P. (2014). "You call it magic": What parents and siblings tell preschoolers about unobservable entities. Journal of Cognition and Development, 15(2), 269-286.

Chouinard, M. M. (2007). Children's questions: A mechanism for cognitive development [Monograph, Serial No: 286]. Society for Research in Child Development, 72(1), 1-126.

Clinical Center National Institutes of Health. (2015). Talking to children about death. Bethesda, MD: NIH Clinical Center Patient Education Materials. 3 Ocak 2016 tarihinde https://clinicalcenter.nih.gov/ccc/patient_education/pepubs/childdeath.pdf adresinden erişildi.

Compayre, G. (1902). Development of the child in later infancy. New York: D. Appleton and Company.

Corriveau, K. H., \& Kurkul, K. E. (2014). “Why does rain fall?”: Children prefer to learn from an informant who uses noncircular explanations. Child Development, 85(5), 1827-1835.

Davis, E. A. (1932). The form and function of children's questions. Child Development, 3(1), 57-74.

Engel, S. (2011). Children's need to know: Curiosity in schools. Harvard Educational Review, 81(4), 625-645.

Essa, E. L. (2013). Introduction to early childhood education. California: Wadsworth Publishing.

Flammer, A. (1981). Towards a theory of question asking. Psychological Research, 43, 407-420.

Frazier, B. N., Gelman, S. A., \& Wellman, H. M. (2009). Preschoolers' search for explanatory information within adult-child conversation. Child Development, 80(6), 1592-1611. 
Frazier, B. N., Gelman, S. A., \& Wellman, H. M. (2016). Young children prefer and remember satisfying explanations. Journal of Cognition and Development, 17(5), 718-736.

Frisancho, S. (2011). Science and religion in education: How to respond to children's questions. Journal of Moral Education, 40(1), 129-132.

Fritzley, V. H., \& Lee, K. (2003). Do young children always say yes to yes-no questions? A metadevelopmental study of the affirmation bias. Child Development, 74(5), 1297-1313.

Goldman, L. (2009). Great answers to difficult questions about death. London: Jessica Kingsley Publishers.

Goldman, L. (2010). Great answers to difficult questions about sex. London: Jessica Kingsley Publishers.

Goody, E. N. (1978). Questions and politeness: Strategies in social interaction. Cambridge: Cambridge University Press.

Greif, M. L., Nelson, D. G. K., Keil, F. C., \& Gutierrez, F. (2006). What do children want to know about animals and artifacts?: Domain-specific requests for information. Psychological Science, 17(6), 455-459.

Harlen, W. (1996). The teaching of science in primary schools. London: David Fulton Publisher.

Harris, G. E. (2012b). Big questions from little people and simple answers from great minds. New York: HalperCollins Publishers.

Harris, P. L. (2012a). Trusting what you're told: How children learn from others. Cambridge, MA: Belknap Press/Harvard University Press.

Harris, P. L. (2000). On not falling down to earth. K. Rosengren, C. Johnson ve P. L. Harris (Ed.), Imagining the impossible: Magical, scientific, and religious thinking in cbildren içinde (s. 157-178). Cambridge: Cambridge University Press.

Harris, P. L., \& Koenig, M. A. (2006). Trust in testimony: How children learn about science and religion. Child Development, 77(3), 505-524.

Harris, P. L., Bartz, D. T., \& Rowe, M. L. (2017). Young children communicate their ignorance and ask questions. Proceedings of the National Academy of Sciences, 114, 7884-7891.

Havigerova, J. M., \& Juklova, K. (2011). School: Institution where children learn the answers without asking question?. Procedia - Social and Behavioral Sciences, 29, 1091-1095.

Hedges, H., \& Cooper, M. (2016). Inquiring minds: Theorizing children's interests. Journal of Curriculum Studies, 48(3), 303-322.

Heller, J. R., \& Johnson, H. L. (2010). What are parents really saying when they talk with their children about sexuality? American Journal of Sexuality Education, 5(2), 144-170.

Herlem, F. C. (2006). Great answers to difficult questions about adoption. London: Jessica Kingsley Publishers. 
Hunnicutt, C. W. (1949). Answering children's questions. New York: Bureau of Publications, Teachers College, Columbia University.

Isaacs, N. (1930). Children's “why” questions. S. Isaacs (Ed.), Intellectual growth in young children içinde (s. 291 - 349). London: Routledge.

James, S. L., \& Seebach, M. A. (1982). The pragmatic function of children's questions. Journal of Speech and Hearing Research, 25, 2-11.

Jamieson, W. (2007). Father knows less. New York: Penguin Group.

Jaswal, V. K., \& Malone, L. S. (2007). Turning believers into skeptics: 3-year-olds' sensitivity to cues to speaker credibility. Journal of Cognition and Development, 8(3), 263-283.

Kemler Nelson D. G., Egan L. C., \& Holt, M. (2004). When children ask, 'What is it?' What do they want to know about artifacts? Psychological Science, 15, 384-389.

Kemler Nelson, D. G., \& O’Neil, K. (2005). How do parents respond to children's questions about the identity of artifacts? Developmental Science, 8, 519-524.

Koenig, M., Clement, F., \& Harris, P. L. (2004). Trust in testimony: Children's use of true and false statements. Psychological Science, 15, 694-698.

Kurkul, K. E., \& Corriveau, K. H. (2018). Question, explanation, follow-up: A mechanism for learning from others? Child Development, 89(1), 280-294.

Legare, C. H., Mills, C. M., Souza, A. L., Plummer L. E., \& Yasskin, R. (2013). The use of questions as problem-solving strategies during early childhood. Journal of Experimental Child Psychology, $114,63-76$.

MacNaughton, G., \& Williams, G. (1998). Techniques for teaching young children. Choices in theory and practice. South Melbourne, Australia: Longman.

Martin, K. A. \& Torres, J. M. C. (2013). Where did I come from? US parents' and preschool children's participation in sexual socialisation. Sex Education: Sexuality, Society and Learning, (14)2, 174-190.

Mercer, N. (2000). Words and minds: How we use language to think together. London: Routledge.

Mills, C. M., \& Landrum, A. R. (2016). Learning who knows what: children adjust their inquiry to gather information from others. Frontiers in Psychology, 7, 1-12.

Mills, C. M., Legare, C. H., Bills, M., \& Mejias, C. (2010). Preschoolers use questions as a tool to acquire knowledge from different sources. Journal of Cognitive and Development, 11(4), 533560 .

Mills, C. M., Legare, C. H., Grant, M. G., \& Landrum, A. R. (2011). Determining who to question, what to ask, and how much information to ask for: The development of inquiry in young children. Journal of Experimental Child Psychology, 110, 539-560.

Morrison, G. S. (2018). Early childhood education today (14. bask1). NewYork: Pearson Publication.

$$
\begin{aligned}
& \text { Erken Çocukluk Çalışmalanı Dergisi } 2020 \quad \text { Journal of Early Childhood Studies } \\
& \text { Cilt } 4 \cdot \text { Say1 } 3 \cdot \text { Ekim } 2020 \quad \text { Volume } 4 \cdot \text { Issue } 3 \cdot \text { October }
\end{aligned}
$$


Morrison, G. S. (2019). Fundamentals of early childhood education (9. Edition). Ohio: Pearson Publication.

Nightingale, B., \& Payne, S. (2013). Early childhood education and care. J. Taylor, E. Bond ve M. Woods (Ed.) Early childhood studies içinde, (s. 133-161). London: Hodder Education.

Olsson, L. M. (2013). Taking children's questions seriously: The need for creative thought. Global Studies of Childhood, 3(3), 230-253.

Piaget, J. (1929). The child's conceptions of the world. London: Routledge \& Kegan.

Piaget, J. (1926). The language and thought of the child. New York: Harcourt Brace.

Piaget, J. (1974). The language and thought of the child. (M. Gabain. Trans.). New York: New American Library. (Original work published 1923).

Piaget, J. (1969). The psychology of intelligence. New York: Littlefield, Adams.

Riihelä, M. (2003). How do we deal with children's questions? Finland: National Research and Development Centre for Welfare and Health.

Ronfard, S., Zambrana, I. M., Hermansen, T. K., \& Kelemen, D. (2018). Question-asking in childhood: A review of the literature and a framework for understanding its development. Developmental Review, 49, 101-120.

Ross, H. S., \& Killey, J. C. (1977). The effect of questioning on retention. Child Development, 48, 312-314.

Rowland, C. F. (2006). Explaining errors in children’s questions. Cognition, 104, 106-134.

Ruggeri, A., \& Lombrozo, T. (2015). Children adapt their questions to achieve efficient search. Cognition, 143, 203-216.

Ruggeri, A., Lombrozo, T., Griffiths, T. L., \& Xu, F. (2015). Children search for information as efficiently as adults, but seek additional confirmatory evidence. 37. Annual Conference of the Cognitive Science Society'de bildiri olarak sunulmuştur.

Sak, R. (2020). Preschoolers' difficult questions and their teachers' responses. Early Childhood Education Journal, 48, 59-70.

Sak, R. (2015). Young children's difficult questions and adults' answers. The Anthropologist, 22(2), 293-300.

Sak, R., Şahin-Sak, İ. T., Öneren-Şendil, Ç., \& Taşkın, N. (2020). Eğitim paydaşlarının okul öncesi eğitimin zorunlu olmasına ilişkin görüşleri. Yaşadıkȩa Ë̆itim, 34(1), 58-78.

Sak, R., \& Şahin-Sak, İ. T. (2020). Preschoolers' difficult questions: Variations by informant and gender. European Early Childhood Education Research Journal, 28(4), 534-547.

Salmon, A. K. (2010). Tools to enhance young children's thinking. Young Children, 65(5),26-31. 
Samuelsson, I. P., Johanson, E., Davidsson, B., \& Fors, B. (2000). Student teachers' and preschool children's questions about life - A phenomenographic approach to learning, European Early Childhood Education Research Journal, 8(2), 5-22.

Sands, L., Carr, M., \& Lee, W. (2012). Question-asking and question-exploring. European Early Childhood Education Research Journal, 20(4), 553-564.

Schleifer, M., \& Talwar, V. (2009). Science and religion in education: How to respond to children's questions. Alberta: Detselig Enterprises Ltd.

Schneider, M. F., \& Zuckerberg, J. (1996). Difficult questions kids ask about divorce. New York: Fireside book.

Silva, M., Strasser, K., \& Cain, K. (2014). Early narrative skills in Chilean preschool: Questions scaffold the production of coherent narratives. Early Childhood Research Quarterly, 29, 205213.

Smith, M. E. (1933). The influence of age, sex, and situation on the frequency, form and function of questions asked by preschool children. Child Development, 4(3), 201-213.

Stephens, K. (2007b). Respond to kids' questions about difference. Parenting Exchange, 1-2.

Stephens, K. (2007a). Respond to support healthy sexual development and values. Parenting Exchange, 1-3.

Sully, J. (1896). Studies of Childhood. New York: D. Appleton and Company.

Sylva, K., E., Melhuish, P. Sammons, I. Siraj-Blatchford, \& B. Taggart. (2010). Early childhood matters: Evidence from the effective pre-school and primary education project. London: Routledge.

Şahhüseyinoğlu, D. (2010). Children as researchers: a report from 6 year old Turkish students 'science' classroom. Procedia Social and Behavioral Sciences, 2, 5152-5156.

Test, J. E. (1988). Communicative interactions between infants and adults at day care and at home: A comparison of Sweden and the United States. Yayımlanmamış Doktora Tezi, Harvard Üniversitesi, Boston.

Test, J. E., Cunningham, D. D., \& Lee, A. C. (2010). Talking with young children: How teachers encourage learning. Dimensions of Early Childhood, 38(3), 3-14.

Tienken, C. H., Goldberg, S., \& Dirocco, D. (2009). Questioning the questions. Kappa Delta Pi Record, 46(1), 39-43.

Tizard, B., \& Hughes, M. (1984). Young children learning. London, UK: Fontana.

Tizard, B., Hughes, M., Carmichael, H. \& Pinkerton, G. (1983). Children's questions and adults' answers. Journal of Child Psychology and Psychiatry, 24, 269 - 281.

Tyack, D., \& Ingram, D. (1977). Children's production and comprehension of questions. Journal of Child Language, 4, 211-224. 
Valian, V., \& Casey, L. (2003). Young children's acquisition of wh-questions: The role of structured input. Journal of Child Language, 30, 117-143.

VanderBorght, M., \& Jaswal, V. K. (2009). Who knows best? Preschoolers sometimes prefer child informants over adult informants. Infant and Child Development, 18, 61-71.

Volbert, R. (2000). Sexual knowledge of preschool children. Journal of Psychology \& Human Sexuality, 12(1-2), 5-26.

Vygotsky, L. (1978). Mind in society: Development of higherpsychologicalprocesses. Cambridge, MA: Harvard University Press.

Was, A. M., \& Warneken, F. (2017). Proactive help-seeking: Preschoolers know when they need help, but do not always ask for it. Cognitive Development, 43, 91-105.

Wode, H. (1971). Some stages in the acquisition of questions by monolingual children. Word, 27(13), 261-310.

Whittaker, A. (2012). Should we be encouraging pupils to ask more questions?. Educational Studies, $38(5), 587-591$.

Yaden, D. B., Smolkin, L. B., \& Conlon, A. (1989). Preschoolers' questions about pictures, print conventions, and story text during reading aloud at home. Reading Research Quarterly, 24(2), 188-214. 